\title{
Prevalence of Endo-parasites in Peafowls (Pavo cristatus) under Captivity Stress and Ameliorative Effect of Anti-Helminthic Drugs
}

\author{
Arnab Tanveer, Shabana Naz*, Azhar Rafique and Asma Ashraf \\ Department of Zoology, Government College University, Faisalabad, Pakistan
}

\begin{abstract}
A B S T R A C T
A study was conducted to find the prevalence of endo-parasites in Pavo cristatus and the comparative efficacy of Albandazole and Levamisole against the endo parasites at three different locations viz. Jallo Wildlife Park Lahore, Wildlife Park Murree and Wildlife Park Bahawalnagar. Freshly dropped fecal sample were collected once before treatment with anthelminthic drug and twice after treatment and brought to laboratory for qualitative and quantitative analysis. Direct smear method and fecal floatation technique was used for isolation and identification of endo-parasites. Modified McMaster technique was used to calculate Eggs per gram. The data was subjected to ANOVA and Tukey-HSD (post hoc test). Six species of endo-parasites were identified from Jallo Wildlife Park. Eimeria (7500) and Ascaris (1100) were the most abundant. Murree Wildlife park had only two species i.e. Eimeria (3850) and Strongyloides (350). In Bahawalanagar Wildlife Park, 4 species of endo-parasites were found (Eimeria $=1450$, Strongyloides $=550$, Heterakis $=350$ and Hymenolepsis $=550$ ). Levamisole was more efficient against endo-parasites as compared to Albandazole. Efficacy of Levamisole at Lahore, Murree and Bahawalnagar wildlife parks after 15 days was $98.36 \%, 92.85 \%$ and $84.48 \%$ respectively as compared to Albandazole whose efficacy was $94.53 \%, 78.57 \%$ and $53.44 \%$, respectively.
\end{abstract}

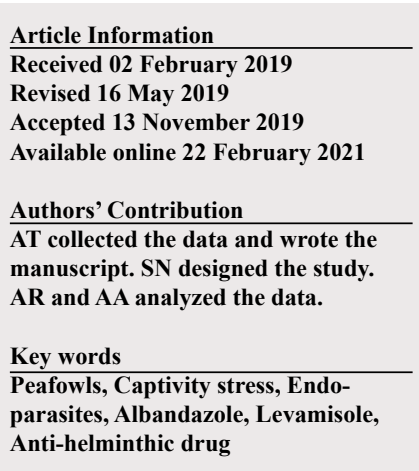

\section{INTRODUCTION}

A large number of wild animals and birds are kept in captivity. Captivity can be a zoo, wildlife park, sanctuary, breeding farm and privately owned farm. The purpose of keeping animals and birds in captivity can be conservation, recreation, economic benefits and research (Varadharajan and Kandasamy, 2000). Captivity produces stress in the birds which make them more susceptible to variety of infections as compared to their counterparts in the wild. Captivity stress could be limited space in the enclosures, overcrowding, unnatural habitat, unfriendly environmental conditions and suboptimal management (Athar et al., 2001; Parsani et al., 2003). Under captivity stress, birds also suffer from a number of behavioral problems, improper body functioning, reduced immunity, parasitism and stress-related health.

One of the major stress factors that reduce the performance of the birds is intestinal parasitism (Badran and Lukesova, 2006). Captive birds become susceptible to endo-parasites because of low space, over-crowded enclosures, poor hygiene, improper use of anti-helminthic drugs and finally poor and late health assessments.

\footnotetext{
* Corresponding author: drshabananaz@gcuf.edu.pk 0030-9923/2021/0002-0627 \$ 9.00/0

Copyright 2021 Zoological Society of Pakistan
}

All these factors become the cause of easy transmission of endo-parasites from one bird to another (Pradeep et al., 2017). Consequently, the birds may suffer from subclinical conditions of anorexia, depression, emaciation, enteritis, and anemia (Forrester et al., 1978). The endo-parasites also damage the health of birds by consuming their nutrients leading to decreased feed utilization, intestinal obstruction and production of toxins and ultimately death may occur (Pradeep et al., 2017).

A broad range of drugs have been used against helminthes, however, resistance has been reported in small ruminants and other livestock animals (Saddiqi et al., 2006; Jabbar et al., 2008), probably affected by the intrinsic efficacy of the drug itself, pharmacokinetic properties, and susceptibility of the host animal and specificity of the parasite (Basit et al., 2014). The present study was conducted to determine the occurrence of endoparasites in Indian peafowl kept in captivity and to find the efficacy of Albandazole and Levamisole against these endo-parasites at three different Wildlife Parks of Punjab.

\section{MATERIALS AND METHODS}

\section{Study site}

The present study was conducted at Jallo Wildlife Park, Lahore, Murree Wildlife Park and Bahawalnagar Wildlife Park to determine the rate of infestation by endo-parasites 
Table I. Comparative pre-treatment EPG (mean \pm SE) and prevalence percentage of endo-parasites at Jallo Wildlife Park Lahore, Wildlife Park Murree and Wildlife Park Bahawalnagar.

\begin{tabular}{|c|c|c|c|c|c|c|c|}
\hline $\begin{array}{l}\text { Identified Endo-parasitic } \\
\text { species }\end{array}$ & $\begin{array}{l}\text { Quantitative } \\
\text { analysis }\end{array}$ & $\begin{array}{l}\text { Jallo Wildlife } \\
\text { Park Lahore }\end{array}$ & $\begin{array}{l}\text { Wildlife Park } \\
\text { Murree }\end{array}$ & $\begin{array}{l}\text { Wildlife Park } \\
\text { Bahawalnagar }\end{array}$ & $\mathbf{N}$ & $\mathbf{F}$ & $\begin{array}{l}\text { Level of } \\
\text { significance }\end{array}$ \\
\hline \multirow[t]{3}{*}{ Eimeria } & EPG & $250 \pm 71.99^{\mathrm{a}}$ & $128.3 \pm 53.37^{b}$ & $48.33 \pm 22.9^{c}$ & 30 & 3.615 & 0.031 \\
\hline & EPG & 7500 & 3850 & 1450 & & & \\
\hline & Prevalence\% & 63.33 & 46.67 & 20 & & & \\
\hline \multirow[t]{3}{*}{ Ascaridia } & EPG & $3.33 \pm 3.33$ & $00 \pm 00$ & $00 \pm 00$ & 30 & 1.00 & 0.372 \\
\hline & EPG & 100 & 0 & 0 & & & \\
\hline & Prevalence\% & 3.33 & 0 & 0 & & & \\
\hline \multirow[t]{3}{*}{ Strongyloides } & EPG & $1.67 \pm 1.66$ & $11.67 \pm 5.71$ & $18.97 \pm 8.38$ & 30 & 2.180 & 0.119 \\
\hline & EPG & 50 & 350 & 550 & & & \\
\hline & Prevalence\% & 3.33 & 16.67 & 20 & & & \\
\hline \multirow[t]{3}{*}{ Ascaris } & EPG & $75 \pm 50.95$ & $00 \pm 00$ & $00 \pm 00$ & 30 & 2.167 & 0.121 \\
\hline & EPG & 1100 & 0 & 0 & & & \\
\hline & Prevalence\% & 6.67 & 0 & 0 & & & \\
\hline \multirow[t]{3}{*}{ Heterakis } & EPG & $1.67 \pm 1.66$ & $00 \pm 00$ & $11.67 \pm 8.194$ & 30 & 1.708 & 0.187 \\
\hline & EPG & 50 & 0 & 350 & & & \\
\hline & Prevalence\% & 3.33 & 0 & 6.67 & & & \\
\hline \multirow[t]{3}{*}{ Hymenolepsis } & EPG & $15 \pm 11.781$ & $00 \pm 00$ & $18.33 \pm 8.80$ & 30 & 1.323 & 0.272 \\
\hline & EPG & 350 & 0 & 550 & & & \\
\hline & Prevalence\% & 10 & 0 & 13.33 & & & \\
\hline Overall EPG & & $9150^{\mathrm{a}}$ & $4200^{b}$ & $2900^{c}$ & 90 & 5.666 & 0.005 \\
\hline Overall prevalence $\%$ & & 70 & 56.67 & 46.67 & & & \\
\hline
\end{tabular}

EPG, Eggs per gram; SE, Standard Error; N, No. of birds; Means having different letters in a row are statistically significant $(\mathrm{P}<0.05)$.

at three different temperature ranges in the same season.

\section{Treatment groups}

For treatment of the peafowls with anthelminthic drugs, birds were randomly divided into two groups with 15 birds each. One group was given Albandazole (Group A) while other group was given Levamisole (Group L). Data was collected three times from the same site. Three treatment levels were set. Level 1 pre-treatment (Day 1), Level 2 post-treatment $1^{\text {st }}$ (Day 7) and level 3 post-treatment $2^{\text {nd }}$ (Day 15). Each post-treatment group was further divided into sub-groups for the treatment of Albandazole and Levamisole. Deworming was done after first sampling from all sites. Water was removed from peafowl cages one day before the administration of anthelminthic drugs. Drug was added to drinking water as per prescription on the label. It was given for three days. Water was changed daily and same process repeated again.

\section{Collection offecal samples}

Freshly dropped fecal sample were collected in fecal cups and labeled properly (Keatts et al., 2016). Color, consistency, blood and mucus was noted for each fecal sample. Samples were stored in pack of handling bags with ice packs for safe transport. All samples were analyzed within $24 \mathrm{~h}$ of collection (Kathiravan et al., 2017).

\section{Parasitological examination}

Direct smear method and fecal floatation technique was used for qualitative analysis of gastrointestinal parasites (Hodgson, 1970; Fowler, 1978; Soulsby, 1982). EndoParasites were identified using identification keys by Jaiswal et al. (2013). Modified McMaster technique was used for quantitative analysis (Titilincu et al., 2009). Eggs per gram (EPG) was calculated by using formula: $\mathrm{EPG}=($ Chamber $1+$ Chamber 2) $\times 50$ (Titilincu et al., 2009).

\section{Drug efficacy}

Drug efficacy was calculated using the following formula (Basit et al., 2014):

Drug efficacy $=\frac{\text { Pretreatment EPG }- \text { Posttreatment EPG }}{\text { Pretreatment EPG }} \times 100$ 
Table II. Comparative EPG and prevalence percentage of endo-parasitic species in Indian Peafowl at Wildlife Park of Lahore, Murree and Bahawalnagar.

\begin{tabular}{|c|c|c|c|c|c|c|c|}
\hline \multirow[t]{2}{*}{ Site } & \multirow[t]{2}{*}{ Species } & & \multirow[t]{2}{*}{ Control } & \multicolumn{2}{|c|}{ Albandazole } & \multicolumn{2}{|c|}{ Levamisole } \\
\hline & & & & Day 7 & Day 15 & Day 7 & Day 15 \\
\hline \multirow[t]{12}{*}{ Jallo Wildlife Park, Lahore } & Eimeria & EPG & 7500 & 500 & 250 & 250 & 150 \\
\hline & & Prevalence $\%$ & 63.33 & 53.33 & 20 & 33.33 & 20 \\
\hline & Ascaridia & EPG & 100 & 0 & 0 & 0 & 0 \\
\hline & & Prevalence $\%$ & 3.33 & 0 & 0 & 0 & 0 \\
\hline & Strongyloides & EPG & 50 & 0 & 0 & 0 & 0 \\
\hline & & Prevalence $\%$ & 3.33 & 0 & 0 & 0 & 0 \\
\hline & Ascaris & EPG & 1100 & 0 & 0 & 0 & 0 \\
\hline & & Prevalence\% & 6.67 & 0 & 0 & 0 & 0 \\
\hline & Heterakis & EPG & 50 & 0 & 0 & 0 & 0 \\
\hline & & Prevalence $\%$ & 3.33 & 0 & 0 & 0 & 0 \\
\hline & Hymenolepsis & EPG & 350 & 0 & 0 & 0 & 0 \\
\hline & & Prevalence\% & 10 & 0 & 0 & 0 & 0 \\
\hline \multirow[t]{12}{*}{ Wildlife Park Murree } & Eimeria & EPG & 3850 & 900 & 350 & 600 & 300 \\
\hline & & Prevalence $\%$ & 46.67 & 33.33 & 33.33 & 33.33 & 26.66 \\
\hline & Ascaridia & EPG & 0 & 0 & 0 & 0 & 0 \\
\hline & & Prevalence $\%$ & 0 & 0 & 0 & 0 & 0 \\
\hline & Strongyloides & EPG & 350 & 0 & 0 & 100 & 0 \\
\hline & & Prevalence $\%$ & 16.67 & 0 & 0 & 33.33 & 0 \\
\hline & Ascaris & EPG & 0 & 0 & 0 & 0 & 0 \\
\hline & & Prevalence $\%$ & 0 & 0 & 0 & 0 & 0 \\
\hline & Heterakis & EPG & 0 & 0 & 0 & 0 & 0 \\
\hline & & Prevalence $\%$ & 0 & 0 & 0 & 0 & 0 \\
\hline & Hymenolepsis & EPG & 0 & 0 & 0 & 0 & 0 \\
\hline & & Prevalence\% & 0 & 0 & 0 & 0 & 0 \\
\hline \multirow[t]{12}{*}{ Wildlife Park Bahawalnagar } & Eimeria & EPG & 1450 & 950 & 300 & 850 & 450 \\
\hline & & Prevalence $\%$ & 20 & 20 & 33.33 & 20 & 20 \\
\hline & Ascaridia & EPG & 0 & 0 & 0 & 0 & 0 \\
\hline & & Prevalence $\%$ & 0 & 0 & 0 & 0 & 0 \\
\hline & Strongyloides & EPG & 550 & 400 & 200 & 350 & 0 \\
\hline & & Prevalence $\%$ & 20 & 13.33 & 20 & 20 & 0 \\
\hline & Ascaris & EPG & 0 & 0 & 0 & 0 & 0 \\
\hline & & Prevalence $\%$ & 0 & 0 & 0 & 0 & 0 \\
\hline & Heterakis & EPG & 350 & 0 & 0 & 0 & 0 \\
\hline & & Prevalence $\%$ & 6.67 & 0 & 0 & 0 & 0 \\
\hline & Hymenolepsis & EPG & 550 & 0 & 0 & 0 & 0 \\
\hline & & Prevalence $\%$ & 13.33 & 0 & 0 & 0 & 0 \\
\hline
\end{tabular}

Prevalence percentage

Prevalence percentage was calculated by using formula:

$$
\text { Prevalence } \%=\frac{\text { No. of infected birds }}{\text { No. of examined birds }} \times 100
$$

Data analysis

Results were analyzed using SPSS software. Normality and homogeneity of variances were checked for all variables. The data was subjected to one-way ANOVA. Tukey-HSD test was performed as a post hoc test for 
pairwise comparisons of means. Significance level was set at $\mathrm{P}<0.05$. Standard Deviation (SD) in post treatment analysis (Table IV) was greater than mean because data was widely distributed about mean. The SD is a description of data's spread. Large SD indicates the data are more spread out while smaller SD shows that data clustered around the mean value. After treatment number of eggs per sample varied from zero (no eggs) to few hundreds (e.g. 200, 500 etc.). Since data had very vast spread about, it had larger SD than mean (Zar, 1999; Isotalo, 2001).

\section{RESULTS}

The results of parasitic egg count of different gastrointestinal parasites in Jallo Wildlife Park Lahore, Wildlife Park Murree and Wildlife Park Bahawalnagar are given in Table I. Eimeria (Fig. 1A) was significantly high $(\mathrm{P}<0.05)$ in Jallo Wildlife Park compared to Wildlife Park Murree and Wildlife Park Bahawalnagar. Similarly, overall egg count was also significantly high at Jallo Wildlife Park Lahore as compared to the other two parks. There was no significant difference in Ascaridia (Fig. 1B), Strongyloides (Fig. 1C), Ascaris (Fig. 1D), Heterakis (Fig. 1E) and Hymenolepsis (Fig. 1F) in the three locations.
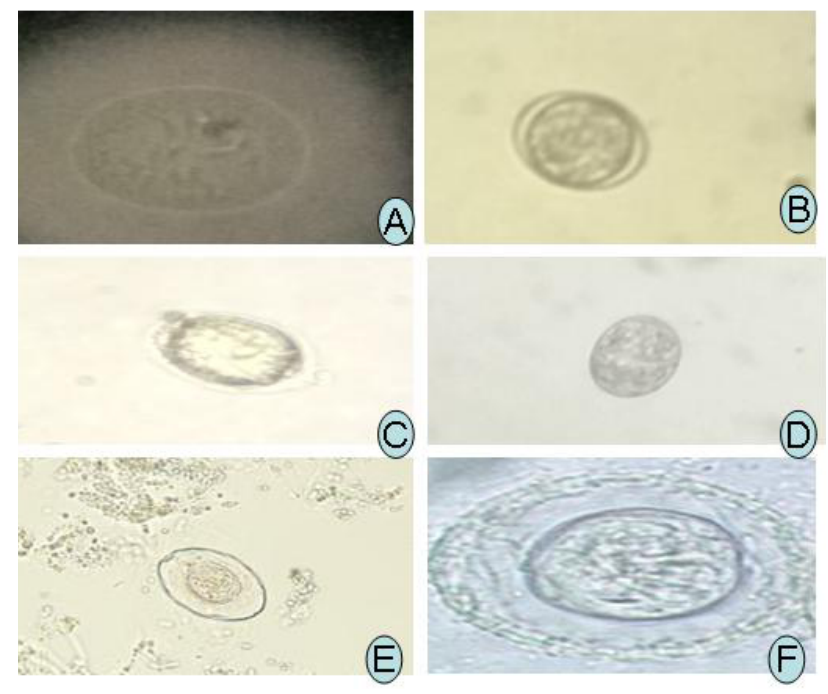

Fig. 1. Morphological identification of the ova of different species. Eimeria (A); Ascaridia (B); Strongyloides (C); Ascaris (D); Heterakis (E); Hymenolepsis (F).

As shown in Table II and III, Levamisole was more effective than Albandazole at all three sites. Efficacy of Levamisole at Lahore, Murree and Bahawalnagar after 15 days was $98.36 \%, 92.85 \%$ and $84.48 \%$, respectively as compared to Albandazole whose efficacy was $94.53 \%$, $78.57 \%$ and $53.44 \%$, respectively.
In post-treatment fecal analysis, only two species were found. That is why all null results were excluded from statistical analysis (Table IV). Eimeria and Strongyloides EPG varied significantly in post treatment levels $(\mathrm{F}=3.749$, $\mathrm{P}=0.054 ; \mathrm{F}=2.323, \mathrm{P}=0.017)$ and at each site $(\mathrm{F}=3.141$, $\mathrm{P}=0.046 ; \mathrm{F}=5.086 \mathrm{P}=0.07$ ).

Table III. Drug efficacy of Albandazole and Lavamisole at Wildlife Park of Lahore, Murree and Bahawalnagar.

\begin{tabular}{|c|c|c|c|c|}
\hline \multirow[t]{2}{*}{ Anthelminthic drugs } & \multicolumn{2}{|c|}{ Post treatment(7) } & \multicolumn{2}{|c|}{ Post treatment(15) } \\
\hline & EPG & Efficacy \% & EPG & Efficacy \% \\
\hline \multicolumn{5}{|l|}{ Lahore } \\
\hline Albandazole & 500 & 94.53 & 250 & 97.26 \\
\hline Levamisole & 250 & 97.26 & 150 & 98.36 \\
\hline \multicolumn{5}{|l|}{ Murree } \\
\hline Albandazole & 900 & 78.57 & 350 & 91.66 \\
\hline Levamisole & 700 & 83.33 & 300 & 92.85 \\
\hline \multicolumn{5}{|l|}{ Bahawalnagar } \\
\hline Albandazole & 1350 & 53.44 & 600 & 79.31 \\
\hline Levamisole & 1200 & 58.62 & 450 & 84.48 \\
\hline
\end{tabular}

EPG, Eggs per gram.

\section{DISCUSSION}

Qualitative and quantitative analysis of end parasites

It was observed that there is a strong correlation between the prevalence of end parasites and temperature of the areas of the study. A total of 30 samples were analyzed before treatment from each site. Overall prevalence of endoparasites in Jallo Wildlife Park, Wildlife Park Murree and Bahawalnagar was $70 \%, 56.6 \%$ and $46.6 \%$, respectively. Zamora-Vilchis et al. (2012) conducted a study on the prevalence of end parasites in lowland and upland areas and found that the parasites were more prevalent in the areas with higher temperature as compared to upland areas. Prevalence of End parasites in peafowls kept at Bhawalnager wildlife Park is less than that of Lahore which can be explained as the moist conditions favor the outbreak of end parasites (Card and Nesheim, 1972; Matter and Oester, 1989). These results are in accordance with results $(56.32 \%$.) of Basit et al. (2014). Results of current study also related to Lierz et al. (2002). He studied endo-parasites in 84 birds of prey and owls in Germany with overall prevalence of $58.3 \%$. Similar trends can be seen in studies of Patel et al. (2000) who reported $48 \%$ overall prevalence, $68 \%$ was reported by Wojcik et al. (1999) and Varghese (1987) concluded 67.3\%. Pal and Ahmed (1985) reported 69\% overall prevalence whereas Kurt and Acici (2008) found prevalence percentage of $88 \%$. Phiri et al. (2007) found that $95 \%$ of the study birds were infected. Eshetu et al. (2001) reported prevalence of 91.01\% while Poulsen et al. (2000) reported 100\% prevalence of endo-parasites. 
Table IV. Comparative analysis of post-treatment EPG mean \pm SE of Eimeria and Strongyloides at Wildlife Park of Lahore, Murree and Bahawalnagar $(n=45)$.

\begin{tabular}{|c|c|c|c|c|c|c|c|c|}
\hline & \multicolumn{4}{|c|}{ Eimeria } & \multicolumn{4}{|c|}{ Strongyloides } \\
\hline & PostA1 & PostL1 & PostA2 & PostL2 & PostA1 & PostL1 & PostA2 & PostL2 \\
\hline $\mathrm{L}$ & $33.3 \pm 1.1^{\mathrm{a}-\mathrm{a}}$ & $10 \pm 0.7^{\mathrm{b}-\mathrm{a}}$ & $16.6 \pm 3.1^{\mathrm{c}-\mathrm{a}}$ & $10 \pm 0.7^{\mathrm{b}-\mathrm{a}}$ & $00 \pm 00$ & $00 \pm 00$ & $00 \pm 00$ & $00 \pm 00$ \\
\hline M & $60 \pm 1.29^{\mathrm{a}-\mathrm{b}}$ & $40 \pm 1.6^{\mathrm{b}-\mathrm{b}}$ & $23.3 \pm 1.6^{\mathrm{c}-\mathrm{b}}$ & $20 \pm 1.4^{\mathrm{d}-\mathrm{b}}$ & $00 \pm 00^{\mathrm{a}-\mathrm{a}}$ & $6.6 \pm 1.5^{\mathrm{b}-\mathrm{a}}$ & $00 \pm 00^{\mathrm{a}-\mathrm{a}}$ & $00 \pm 00^{\mathrm{a}-\mathrm{a}}$ \\
\hline B & $63.3 \pm 1.87^{\mathrm{a}-\mathrm{c}}$ & $56.6 \pm 1.7^{\mathrm{b}-\mathrm{c}}$ & $20 \pm 1.6^{c-c}$ & $30 \pm 1.9^{\mathrm{d}-\mathrm{c}}$ & $26.6 \pm 0.3^{\mathrm{a}-\mathrm{b}}$ & $23.3 \pm 1.5^{\mathrm{b}-\mathrm{b}}$ & $13.3 \pm 2.6^{\mathrm{c}-\mathrm{b}}$ & $00 \pm 00^{\mathrm{d}-\mathrm{b}}$ \\
\hline Total & $52.2 \pm 1.8^{\mathrm{a}-\mathrm{c}}$ & $35.5 \pm 1.5^{\mathrm{b}-\mathrm{d}}$ & $20 \pm 3.9^{\mathrm{c}-\mathrm{c}}$ & $20 \pm 4.7^{\mathrm{c}-\mathrm{d}}$ & $8.8 \pm 2.5^{\mathrm{a}-\mathrm{c}}$ & $10 \pm 1.2^{\mathrm{b}-\mathrm{c}}$ & $4.4 \pm 1.9^{\mathrm{c}-\mathrm{c}}$ & $00 \pm 00^{\mathrm{d}-\mathrm{c}}$ \\
\hline
\end{tabular}

$\mathrm{N}$, Total no. of samples examined; Means having different letters in a row or in a column are statistically significant $(\mathrm{P}<0.05)$. PostA1, Post-treatment First, subgroup Albandazole; PostL1, Post-treatment First, subgroup Levamisole; PostA2, Post-treatment Second, subgroup Albandazole; PostL2, Post-treatment Second, subgroup Levamisole; L, Lahore; M, Murree; B, Bahawalnagar.

In the present study prevalence of Heterakis in two sites was very low compared to other studies. Heterakis prevalence was $3.33 \%$ in Jallo, and $6.67 \%$ in Bahwalnagar while in fecal samples from Muree Wildlife Park no Heterakis was found. On the contrary in a study by Basit et al. (2014), relative prevalence of Heterakis was $36.73 \%$ and $29 \%$ was reported by Kurt and Acici (2008) in a study on chicken. Prevalence of Ascaridia in current study was $3.33 \%$ and it was found only in Jallo Wildlife Park. Contradicting results are seen in study by Basit et al. (2014) who found 26.53\% prevalence of Ascaridia and $28.8 \%$ was reported by Phiri et al. (2007).

Relative prevalence of endo-parasites in Indian Peafowl at Jallo Wildlife Park was maximum i.e. $70 \%$ followed by $56.67 \%$ in Murree and $46.67 \%$ in Bahawalnagar Wildlife Park (Table I). Number of infected birds were more at Jallo Wildlife Park (21) and Wildlife Park of Murree (21) as compared to Bahawalnagar (14). It is established fact that better management conditions lessen the chances of parasitic infections. This claim is also supported by Sascnyanga (1982) where he reported the infestation by Ascaridia galli was more (49\%) in birds kept under ordinary conditions and only $8 \% \mathrm{~A}$. galli were found in birds under good conditions. He further added that changes in prevalence of endo-parasites at various localities might be due to changed climatic conditions and management practices. Higher prevalence rate like $88 \%$, $95.2 \% 91.01 \%$ and even $100 \%$ is reported by Kurt and Acici (2008), Phiri et al. (2007), Eshetu et al. (2001) and Poulsen et al. (2000) respectively.

\section{Drug efficacy}

In present study it was found that Levamisole was more effective than Albandazole at all the three sites. Efficacy of Levamisole at Jallo Wildlife Park Lahore, Murree Wildlife Park and Bahawalnagar Wildlife Park after 15 days was $98.36 \%, 92.85 \%$ and $84.48 \%$ respectively compared to Albandazole with efficacy of $94.53 \%, 78.57 \%$ and $53.44 \%$ in respective Wildlife Parks and are in accordance with Basit et al. (2014) who found the efficacy of Albandazole being $94.92 \%$ at $10^{\text {th }}$ day. Ashraf et al. (2002) observed 95.79\% efficacy of Albandazole against endo-parasitic nematodes. Similar trend was observed by Villanua et al. (2007). In a study on Red Legged Partridges, efficacy of Albandazole against endo-parasites was only $38.8 \%$. Khan et al. (2010) concluded that Albandazole was more effective (96.33\%) than Levamisole (84.90\%). However, a study by Sharma et al. (1989) and Clarkson and Beg (1970) reported results similar to current study. They stated that Levamisole was $100 \%$ effective against endo-parasites as it inhibits activity of malate dehydrogenase.

In present study Albandazole and Levamisole were $100 \%$ efficient against all endo-parastites except Eimeria. Jiang and Li (1985) found 100\% efficacy of Albandazole against A. galli. Albandazole was 100\% effective against Strongyloides in both sites except in Wildlife Park Bahawalnagar where after 15 days prevalence of Strongyloides was $20 \%$ with EPG of 200. This anomaly in efficacy may be attributed to genetic resistant of namatodes against repetitive use of Albandazole. Schou (2003) also observed a similar trend. He reported that nematodes in cattle showed resistance to use of Albandazole as dewormer especially A. galli.

\section{CONCLUSION}

Levamisole has better effect against gastrointestinal parasites as compared to Albandazole. Albandazole is a commonly used dewormer and endo-parasitic species are developing resistance against it. So it is recommending that with proper hygiene measures, good management practices and use of different dewormers, especially with Levamisole, we may be able to reduce the infestation of animals and birds in captivity by endo-parasites and reduce economic loss. 


\section{ACKNOWLEDEMENT}

We are thankful to Higher Education Commission (HEC) of Pakistan for providing financial support to this research work under the Project No. 5656/Punjab/NRPU/ R\&D/HEC/2016. Thanks are also extended to Mr. Kahlid Ayas, Dr. Zahid Farooq, Mr. Zahid Ali and Mr. Muhammad Abrar, Punjab Wildlife Department for granting permission and technical assistance to conduct this research. We are also grateful to Dr. Rifat Ullah Khan, Department of Animal Health, The University of Agriculture Peshawar, for editing this paper.

\section{Statement of conflict of interest}

Authors have declared no conflict of interest

\section{REFERENCES}

Ashraf, M., Waraich, F.N., Ahmad, I.G. and Pervez, K., 2002. Chemotherapy of gastro-intestinal namatodes in common peafowl (Pavo cristatus). Pak. Vet. J., 22: 91-93.

Athar, M., Shakoor, A., Muhammad, G., Asi, N.M. and Saqib, M., 2001. Surgical rectification of threadassociated Glossoptosis in peafowls. Pak. Vet. J., 21: 92-94.

Badran, I. and Lukesova, D., 2006. Control of coccidiosis and different coccidia of chicken in selected technologies used in tropics and subtropics. Agric. trop. Subtrop., 1: 39-44.

Basit, A., Ali, A.A., Malik, M.S., Malik, A.N., Iftikhar, M., Haq, H. and Nadeem, S.M., 2014. A study of gastrointestinal helminths in native peafowl and comparative efficacy of Albendazol and a Pyrantel pamoate against the helminth parasites. J. Infect. mol. Biol., 2: 22-25. https://doi.org/10.14737/ jimb.2307-5465/2.2.22.25

Card, L.E. and Nesheim, M.C., 1972. Diseases and parasites. In: Poultry production. 11th ed. Lea and Febiger, Philadelphia, PA. Chapter 10. Pages 244273.

Clarkson, M.J. and Beg, M.K., 1970. The anthelmintic activity of L- tetramisole against Ascardia galli and Capillaria obsignata in the fowl. Vet. Rec., 86: 652654. https://doi.org/10.1136/vr.86.22.652

Eshetu, Y., Mulualem, E., Ibrahim, H., Berhanu, A. and Aberra, K., 2001. Study of gastrointestinal helminthes of scavenging chickens in four rural districts of Amhara region, Ethopia. Rev. Sci. Tech., 20: 791 - 796. https://doi.org/10.20506/ rst.20.3.1310

Forrester, D.J., Carpenter, J.W. and Blankinship, J.R.,
1978. Coccidia of whooping cranes. J. Wildl. Dis., 14: 24-27. https://doi.org/10.7589/0090-355814.1.24

Fowler, M.E., 1978. Zoo and wild animal medicine. WB Saunders Company, Philadelphia, Pa.

Hodgson, J., 1970. Coccidiosis: Oocyst counting technique for coccidiostat evaluation. Exp. Parasitol., 28: 99-102. https://doi. org/10.1016/0014-4894(70)90073-1

Isotalo, J., 2001. Basics of statistics. University of Tampere Finland. pp. 36-39.

Jabbar, A., Iqbal, Z., Saddiqi, H.A., Babar, W. and Saeed, M., 2008. Prevalence of multiple anthelmintic resistant gastrointestinal nematodes in dairy goats in a desolated tract (Pakistan). Parasitol. Res., 103: 29-35. https://doi.org/10.1007/s00436-008-0923-6

Jaiswal, A.K., Sudan, V., Shanker, D. and Kumar, P., 2013. Endoparasitic infections in Indian peacocks (Pavo cristatus) of Veterinary College Campus, Mathura. J. Parasit. Dis., 37: 26-28. https://doi. org/10.1007/s12639-012-0124-1

Jiang, Y.P. and Li, Z.D., 1985. Anthelmintic efficacy of Albendazole against Ascardia galli. China. J. Vet. Med., 10: 40-41.

Kathiravan, R., Ramachandran, P., Shanmuganathan, S., Karthikeyan, A., Sathiyamoorthy, N., Gollapalli, S., Silambarasan, R., Bhinsara, D. and Madesh, E., 2017. Prevalence of endoparasitic infection in free ranging peacocks of Southern Tamil Nadu, India. Int. J. Curr. Microbiol. appl. Sci., 6: 366-371. https://doi.org/10.20546/ijcmas.2017.610.045

Keatts, L., Fine, D.A. and Consortium, P.O.H., 2016. PREDICT operating procedures: Avian sampling. Methods, 23: 4-6.

Khan, M.A., Khan, M.S., Shafee, M. and Khan, J.A., 2010. Prevalence and chemotherapy of helminthiasis in parrots at Lahore Zoo, Pakistan. $J$. Anim. Pl. Sci., 20: 189-192.

Kurt, M. and Acici, M., 2008. Cross-sectional survey on helminth infections of chickens in the Samsun region, Turkey. Dtsch. Tierarztl. Wochenschr., 115: 239-242.

Lierz, M., Gobel, T. and Schuster, R., 2002. Occurrence of parasites in indigenous birds of prey and owls. Berl. Munch. Tierarztl. Wochenschr., 115: 43-52.

Matter, F. and Oester, H., 1989. Hygiene and welfare implications of alternative husbandry systems for laying hens. In: Proceedings from the $3^{\text {rd }}$ European symposium on poultry welfare (eds. J.M. Faure and D. Mills). Tours, France, pp. 201-212.

Pal, R.A. and Ahmed, K.N., 1985. A survey of intestinal helminthes of poultry in some districts of Punjab 
and NWFP. Pakistan J. Zool., 17: 193-200.

Parsani, H.R., Monim, R.R., Sahu, R.K. and Patel, B.G., 2003. Prevalence of gastro-intestinal parasites in captive birds at Kamla Nehru Zoological Garden, Kankaria Zoo, Ahmedabad, Gujarat. Zoos' Print J., 18: 987-992. https://doi.org/10.11609/JoTT. ZPJ.18.1.987-92

Patel, P.V., Patel, A.I., Sahu, R.K. and Raju, V., 2000. Prevalence of gastro-intestinal parasites in captive birds of Gujarat Zoos. Zoos' Print J., 15: 295-296. https://doi.org/10.11609/JoTT.ZPJ.15.7.295-6

Phiri, I.K., Phiri, A.M., Ziela, M., Chota, A., Masuku, M. and Monrad, J., 2007. Prevalence and distribution of gastrointestinal helminths and their effects on weight gain in free-range chickens in Central Zambia. Trop. Anim. Hlth. Prod., 39: 309-315. https://doi.org/10.1007/s11250-007-9021-5

Poulsen, J., Permin, A., Hindsbo, O., Yelifari, L., Nansen, P. and Bloch, P., 2000. Prevalence and distribution of gastro-intestinal helminthes and haemoparasites in young scanvenging chickens in upper eastern region of Ghana, West Africa. Prev. Vet. Med., 45: 237-245. https://doi.org/10.1016/ S0167-5877(00)00125-2

Pradeep, R., Senthilkumar, A., Sangaran, A., Prathaban, S. and Pradeep, A., 2017. Incidence of endoparasites in captive pheasants in Arignar Anna Zoological Park, Vandalur, Chennai. Int. J. Curr. Microbiol. appl. Sci., 6: 2517-2521. https://doi.org/10.20546/ ijcmas.2017.609.309

Saddiqi, H.A., Jabbar, A., Iqbal, Z., Babar, W., Sindhu, Z.U.D. and Abbas, R.Z., 2006. Comparitive efficacy of five anthelmintics against trichostrongylid nematodes in sheep. Can. J. Anim. Sci., 86: 471477. https://doi.org/10.4141/A06-036

Sascnyanga, G.S., 1982. Prevalence of helminth parasites of domestic fowl in Uganda. Trop. Ani. Hlth. Prod., 14: 201-204. https://doi.org/10.1007/ BF02242158

Schou, T., Permin, A., Roepstorff, A., Srensen, P. and Kjaer, J., 2003. Comparative genetic resistance to
Ascaridia galli infections of 4 different commercial layer-lines. Br. Poult. Sci., 44: 182-185. https://doi. org/10.1080/00071660301952

Sharma, R.K., Singh, K. and Saxena, K.K., 1989. The effect of levamisole and albendazole on some enzymes of Ascaridia galli and Heterakis gallinae. Vet. Parasitol., 30: 213-222. https://doi. org/10.1016/0304-4017(89)90017-4

Soulsby, E.J.L., 1982. Helminths, arthropods and protozoa of domestic animals. $7^{\text {th }}$ edn. Baillere Tindall, London. pp. 765-766.

Titilincu, A., Mircean, V., Bejan, A., Iovu, A., Ungureanu, R. and Cozma, V., 2009. Prevalence of endoparasites in peacocks (Pavo cristatus). Sci. Parasitol., 10: 101-105.

Varadharajan, A. and Kandasamy, A., 2000. A survey of gastro-intestinal parasites of wild animals in captivity in the VOC Park and Mini Zoo, Coimbatore. Zoos' Print J., 15: 257-258. https:// doi.org/10.11609/JoTT.ZPJ.15.5.257-8

Varghese, T., 1987. Endoparasites of birds of paradise in Papua New Guinea. Vet. Parasitol., 26: 131-144. https://doi.org/10.1016/0304-4017(87)90083-5

Villanua, D., Perez, R.L., Rodrique, O., Vinuela, J. and Gortazar, C., 2007. How effective is pre-release nematode control in farm-reared red-legged partridges, Alectoris rufa. J. Helminthol., 81: 101103. https://doi.org/10.1017/S0022149X07251211

Wojcik, A.R., Wasielewski, L., Grygon-Franckiewicz, B. and Zbikowska, E., 1999. Economic losses in pheasant breeding evoked with endoparasites. Wiad Parazytol., 45: 363-368.

Zamora-Vilchis, I., Williams, S.E. and Johnson, C.N., 2012. Environmental temperature affects prevalence of blood parasites of birds on an elevation gradient: Implications for disease in a warming climate. PLoS ONE, 7: e39208. https:// doi.org/10.1371/journal.pone.0039208

Zar, J.H., 1999. Biostatistical analysis. Pearson Education, India. pp. 73-77. 